\title{
Penerapan Metode Dongeng dengan Media Boneka Tangan Sebagai Upaya Meningkatkan Kemampuan Berbicara Anak Kelompok BDI Ra Darussalam Kecamatan Plosoklaten, Kabupaten Kediri
}

\author{
Dania Aptiningsari* \\ Universitas Negeri Malang, Jl. Semarang No. 5 Malang, Jawa Timur, Indonesia \\ *Penulis korespondensi, Surel: aptiningsaridania@gmail.com
}

Paper received: 3-5-2021; revised: 24-5-2021; accepted: 28-5-2021

\begin{abstract}
This study aims to improve the ability to speak through a fairy tale method with hand puppet media on group B children. This research is a classroom action research conducted in cycles. Data collection methods used observation methods with speech ability instruments, field notes and documentation. Data analysis was conducted in quantitative and qualitative descriptive with completeness criteria bigger than or equal to 75 percent. This study was conducted in 2 cycles. The results showed that children's speaking ability in the first cycle of the first meeting reached 33.33 percent, increasing to 59.25 percent in the second meeting. In the second cycle of the first meeting the child's speech ability reached 70.37 percent and increased by 14.81 percent in the second cycle of the second meeting. So the success of the class obtained in the second cycle of the second meeting was 85.18 percent. This shows that learning activities by applying fairytale methods with hand puppet media can improve children's speaking skills in accordance with the expected indicators.
\end{abstract}

Keywords: fairy tale method; hand puppet media; speaking ability

\begin{abstract}
Abstrak
Penelitian ini bertujuan untuk meningkatkan kemampuan berbicara melalui metode dongeng dengan media boneka tangan pada pada anak kelompok B. Penelitian ini merupakan penelitian tindakan kelas yang dilaksanakan bersiklus. Metode pengumpulan data yang digunakan metode observasi dengan instrumen kemampuan berbicara, catatan lapangan dan dokumentasi. Analisis data dilakukan secara deskriptif kuantitatif dan kualitatif dengan kriteria ketuntasan lebih dari atau sama dengan 75 persen. Penelitian ini dilaksanakan 2 siklus. Hasil penelitian menunjukkan kemampuan berbicara anak pada siklus I pertemuan pertama mencapai 33,33 persen meningkat menjadi 59,25 persen pada pertemuan kedua. Pada siklus II pertemuan pertama kemampuan berbicara anak mencapai 70,37 persen dan meningkat sebesar 14,81 persen pada siklus II pertemuan kedua. sehingga keberhasilan kelas yang diperoleh pada siklus II pertemuan kedua sebesar 85,18 persen. Hal ini menunjukkan bahwa kegiatan pembelajaran dengan menerapkan metode dongeng dengan media boneka tangan dapat meningkatkan kemampuan berbicara anak sesuai dengan indikator yang diharapkan.
\end{abstract}

Kata kunci: metode dongeng; media boneka tangan; kemampuan berbicara

\section{Pendahuluan}

Perkembangan bahasa dimulai anak sejak lahir baik dari tangisan pertama, celoteh pertama dan kata-kata pertama yang muncul dalam diri anak (Morrison, 2016). Perkembangan bahasa adalah perkembangan kemampuan berkomunikasi yang mencakup receptive speech, expressive speech, dan artikulasi (Meggit, 2013). Bahasa salah satu hal yang penting, dimana melalui bahasa seseorang dapat mengungkapkan apa yang ingin disampaikan kepada orang lain. Slee (2012) mengungkapkan bahwa "language development is a major achievement in 
infancy and early childhood" yang dimaknai bahwa perkembangan bahasa memiliki peran pencapaian yang besar pada masa bayi dan anak usia dini. Prioritas tertinggi bagi seorang guru pendidikan anak usia dini adalah dapat menyediakan program yang mendukung dan memberikan fasilitas yang memadai bagi perkembangan berbahasa anak (Morisson, 2016). Hal ini dapat difasilitasi melalui kegiatan belajar mengajar yang menyenangkan dan menarik bagi diri anak.

Tahapan perkembangan bahasa pada anak usia dini meliputi kemampuan mendengar, berbicara dan menulis. Kemampuan dalam berbicara merupakan sarana pokok dalam proses sosialisasi (Hurlock, 1980). Perkembangan dalam kemampuan berbicara anak sangat perlu untuk diperhatikan. Kemampuan berbicara yang rendah, maka akan memiliki dampak yang buruk terhadap perkembangan anak yang lain. Kurangnya kemampuan berbicara anak dapat dilihat dari ketidakmampuan anak saat mengungkapkan pendapat dengan sederhana, atau anak yang merasa kesulitan saat melakukan komunikasi dengan orang lain. Kemampuan berbicara yang terbatas tersebut apabila tidak ditangani dengan baik, imbasnya di masa yang akan datang anak akan merasa kesulitan saat harus berkomunikasi dengan orang lain akibat kosakata yang terbatas. Anak-anak membutuhkan kegiatan dialog yang efektif antara orang dewasa dan anak sehingga anak dapat mengajukan pertanyaan dan mendorong anak lebih banyak berbicara (Seefeldt \& Barbara, 2008).

Lingkup perkembangan bahasa anak usia dini menurut Permendikbud Nomor 137 tahun 2014 pada anak usia 5-6 tahun meliputi memahami bahasa, mengungkapkan bahasa dan keaksaraan. Lingkup perkembangan mengungkapkan bahasa anak usia 5-6 tahun ditandai dengan anak mampu menjawab pertanyaan yang lebih kompleks, memiliki perbendaharaan kata yang luas, menyusun kalimat sederhana dengan struktur yang lengkap, melanjutkan cerita atau dongeng yang didengar dan menunjukkan konsep-konsep pada buku cerita. Beberapa indikator tersebut perlu dimiliki oleh anak yang berada di rentang usia 5-6 tahun.

Berdasarkan hasil observasi awal pada anak kelompok B di RA Darussalam, Kecamatan Plosoklaten, Kabupaten Kediri ditemukan beberapa fakta terkait perkembangan bahasa dalam aspek berbicara yang belum berkembang sepenuhnya. Sebanyak 20 anak dari 27 anak kelompok B masih kesulitan dalam berkomunikasi lisan dengan baik, belum memiliki perbendaharaan kosakata yang luas dan belum mampu melanjutkan cerita atau dongeng yang telah diperdengarkan.

Penyebab rendahnya kemampuan berbicara anak di RA Darussalam adalah kegiatan proses pembelajaran yang masih lebih dominan kegiatan individu dibandingkan dengan kegiatan kelompok. Selain itu, guru yang mengajar masih menggunakan metode klasikal dan cenderung menggunakan LKA (Lembar Kerja Anak) dibandingkan kegiatan yang mengasah kemampuan berbicara anak. Guru kelas juga belum memanfaatkan media pembelajaran yang menunjang bagi terlaksananya proses belajar mengajar. Hal inilah yang membuat kegiatan pembelajaran pada kelompok B kurang dapat memberikan ruang kepada anak untuk berkomunikasi dengan teman sebayanya sehingga kemampuan anak dalam berbicara masih belum berkembang dengan baik.

Berdasarkan permasalahan tersebut, kemampuan berbicara anak kelompok B RA Darussalam masih belum optimal. Kegiatan pembelajaran di dalam kelas diperlukan metode dan media yang menarik sehingga kemampuan berbicara anak dapat berkembang. Metode yang diterapkan bagi pembelajaran anak usia dini harus yang menyenangkan dan 
menimbulkan motivasi bagi anak untuk belajar dengan melakukan atau learning by doing. Salah satu metode yang dapat diterapkan oleh guru guna membuat kegiatan belajar mengajar menjadi aktif dan menarik adalah dengan metode dongeng. Metode dongeng erat kaitannya dengan suara dan bahasa (Suyadi, 2015). Metode dongeng atau cerita ini adalah metode pembelajaran yang digunakan oleh guru dengan mengisahkan suatu peristiwa atau kejadian (Fadlillah, 2012). Penggunaan media pembelajaran dalam kegiatan belajar anak usia dini harus tepat dilakukan agar dapat tercapai tujuan yang ingin diraih (Kustiawan, 2016).

Media yang tepat digunakan dalam pembelajaran dapat meningkatkan aspek perkembangan anak usia dini. Salah satu aspek yang penting untuk dikembangkan adalah aspek bahasa kaitannya dengan kemampuan berbicara. Media boneka tangan akan membuat anak menjadi tertarik untuk mengikuti kegiatan belajar mengajar di dalam kelas. Secara tidak langsung, media boneka tangan akan melatih kemampuan berbicara anak. Penggunaan media boneka tangan diharapkan dapat membuat anak tertarik dalam pembelajaran dan merasa senang saat menggunakan media boneka tangan sehingga dapat mengembangkan kemampuan berbicara anak.

Penelitian ini penting dilakukan agar dapat meningkatkan kemampuan berbicara anak melalui penerapan metode dongeng dengan media boneka tangan di kelompok B RA Darussalam. Berdasarkan permasalahan di penelitian atas, penulis merumuskan judul penelitian "Penerapan Metode Dongeng dengan Media Boneka Tangan Pada Anak Kelompok B di RA Darussalam, Kecamatan Plosoklaten, Kabupaten Kediri”

\section{Metode}

Penelitian ini adalah penelitian tindakan kelas (classroom action research). Penelitian tindakan kelas adalah penelitian tindakan yang dilakukan di dalam kelas yang bertujuan untuk memperbaiki atau meningkatkan mutu praktik belajar (Arikunto, 2012). Tujuan dari penelitian ini adalah meningkatkan kemampuan berbicara anak kelompok B RA Darussalam melalui metode dongeng dengan media boneka tangan. Pendekatan penelitian yang digunakan dalam penelitian ini adalah pendekatan kuantitatif dan kualitatif. Penelitian tindakan kelas ini menggunakan model Kemmis \& Mc Taggart. Pada setiap siklus pembelajaran terdapat empat elemen penting yakni perencanaan, pelaksanaan, pengamatan dan refleksi.

Penelitian yang dilakukan ini bersifat kolaboratif, dimana peneliti bekerja sama dengan guru kelas dalam melaksanakan penelitian ini. Peneliti bertindak sebagai perencana kegiatan, pelaksana pembelajaran, pengumpulan, penganalisis dan pelapor hasil penelitian. Guru kelas bertindak sebagai pengamat atau observer dalam menganalisis data dan refleksi dari hasil tindakan yang sudah dilakukan. Subjek penelitian ini adalah anak Kelompok B RA Darussalam, Kecamatan Plosoklaten, Kabupaten Kediri yang berjumlah 27 anak, terdiri dari 9 anak laki-laki dan 18 anak perempuan.

Data yang digunakan dalam penelitian ini adalah data kuantitatif dan kualitatif berupa data peningkatan kemampuan berbicara anak selama penelitian berlangsung. Data yang akan dikumpulkan adalah 1) lembar observasi berupa catatan lapangan dan lembar penilaian kemampuan berbicara, dan 2) dokumentasi berupa foto. Teknik pengumpulan data dalam penelitian ini adalah dengan observasi dan dokumentasi. Pada penelitian ini digunakan instrumen berupa lembar penilaian peningkatan kemampuan berbicara, catatan lapangan dan dokumentasi berupa foto-foto kegiatan. Adapun instrumen lembar observasi peningkatan kemampuan berbicara anak adalah sebagai berikut: 
Jurnal Pembelajaran, Bimbingan, dan Pengelolaan Pendidikan, 1(5), 2021, 362-372

Tabel 1. Instrumen Lembar Observasi Peningkatan Kemampuan Berbicara Anak Usia 5-6 Tahun Melalui

\begin{tabular}{|c|c|c|c|c|c|c|c|c|c|c|c|c|c|c|c|}
\hline \multirow{3}{*}{ No } & \multirow{3}{*}{ Nama } & \multicolumn{12}{|c|}{ Aspek Penilaian Kemampuan Berbicara } & \multirow{3}{*}{ Skor } & \multirow{3}{*}{ Ket } \\
\hline & & \multicolumn{4}{|c|}{$\begin{array}{l}\text { Berkomunikasi } \\
\text { lisan dengan } \\
\text { baik }\end{array}$} & \multicolumn{4}{|c|}{$\begin{array}{l}\text { Memiliki } \\
\text { perbendaharaan } \\
\text { kosakata yang } \\
\text { luas }\end{array}$} & \multicolumn{4}{|c|}{$\begin{array}{l}\text { Mampu } \\
\text { melanjutkan } \\
\text { cerita atau } \\
\text { dongeng } \\
\end{array}$} & & \\
\hline & & 4 & 3 & 2 & 1 & 4 & 3 & 2 & 1 & 4 & 3 & 2 & 1 & & \\
\hline \multicolumn{16}{|l|}{1} \\
\hline \multicolumn{16}{|l|}{2} \\
\hline \multicolumn{16}{|l|}{3} \\
\hline \multicolumn{16}{|c|}{4} \\
\hline \multicolumn{16}{|c|}{ Jumlah anak yang memenuhi ketercapaian } \\
\hline \multicolumn{16}{|c|}{ Jumlah anak yang belum memenuhi ketercapaian } \\
\hline \multicolumn{16}{|c|}{ \% anak yang memenuhi ketercapaian } \\
\hline \multicolumn{16}{|c|}{ Kriteria tingkat ketercapaian kelas } \\
\hline
\end{tabular}

\subsection{Metode Dongeng Dengan Media Boneka Tangan}

Analisis data yang digunakan dalam penelitian ini adalah deskriptif kualitatif dan deskriptif kuantitatif. Data yang dianalisis secara kualitatif merupakan data yang berupa catatan lapangan dan data berupa dokumentasi berupa foto kegiatan pembelajaran. Data yang dianalisis secara kuantitatif merupakan data yang berkaitan dengan peningkatan kemampuan berbicara anak pada skala capaian perkembangan. Adapun rumus nilai modifikasi dari Sudijono (2014) untuk mengetahui skor ketercapaian anak adalah sebagai berikut:

Skor Ketercapaian $=\frac{\text { Jumlah Skor }}{\text { Skor Keberhasilan }} \times 100 \%$

Tabel 2. Kriteria Ketercapaian Belajar Anak dimodifikasi dari (Arikunto, 2010:35)

\begin{tabular}{cc}
\hline Kriteria Kemampuan Anak & Tingkat Keberhasilan \\
\hline $85-100$ & BSB \\
$75-84$ & BSH \\
$55-74$ & $\mathrm{MB}$ \\
$0-54$ & $\mathrm{BB}$ \\
\hline
\end{tabular}

Berdasarkan tabel 2. ketercapaian anak dinyatakan berhasil apabila jumlah nilai anak secara keseluruhan $\geq 75$. Sedangkan persentase penilaian ketercapaian kelas adalah data yang digunakan untuk dapat mengetahui tingkat keberhasilan tindakan yang sudah dilakukan oleh peneliti. Peneliti menghitung jumlah anak yang mendapat skor $\geq 75$, kemudian membagi dengan jumlah keseluruhan anak didik. Menurut Sudijono (2014:41) rumus ketercapaian kelas dapat disajikan sebagai berikut:

$P=\frac{f}{n} \times 100 \%$

Keterangan:

$\mathrm{P}$ : Persentase tingkat perubahan

f : Jumlah anak yang mendapatkan skor $\geq 75$ 
$\mathrm{N}$ : Jumlah anak keseluruhan

$\%$ : Tingkat keberhasilan yang dicapai

Tabel 2. Kriteria Ketercapaian Kelas dimodifikasi dari Arikunto (2010:35)

\begin{tabular}{cc}
\hline Persentase & Keterangan \\
\hline $85-100 \%$ & Sangat Tercapai \\
$75-84 \%$ & Tercapai \\
$55-74 \%$ & Mulai Tercapai \\
$0-54 \%$ & Belum Tercapai \\
\hline
\end{tabular}

Berdasarkan tabel 3. kelas dianggap mencapai keberhasilan apabila persentase yang diperoleh kelas mencapai $\geq 75 \%$. Penentuan ketercapaian anak didasarkan pada acuan lembar pengamatan peningkatan kemampuan berbicara dengan cara menghitung skor yang diperoleh tiap anak. Prosedur penelitian tindakan kelas ini meliputi kegiatan pra tindakan dan siklus I. Jika dalam pelaksanaan siklus I belum ada peningkatan kemampuan berbicara sesuai dengan yang diharapkan, maka penelitian akan berlanjut pada siklus II dan seterusnya hingga diperoleh hasil yang diharapkan.

\section{Hasil dan Pembahasan}

\subsection{Hasil}

\subsubsection{Deskripsi Pra tindakan}

Kegiatan pra tindakan dilakukan sebelum melaksanakan tindakan penelitian. Kegiatan pra tindakan ini dilaksanakan pada tanggal 29 Januari 2019 di RA Darussalam, Kecamatan Plosoklaten, Kabupaten Kediri. Pengamatan dilakukan pada anak TK B yang berjumlah 27 anak. Peneliti melakukan pengamatan dan penelitian awal yang berguna untuk meneliti dan mencari permasalahan pada aspek kemampuan berbicara pada anak TK B. Kegiatan mendongeng yang dilakukan oleh peneliti belum menggunakan media pembelajaran boneka tangan. Kegiatan pra tindakan ini, peneliti berperan sebagai pengamat kegiatan dan guru kelas sebagai pelaksana pembelajaran.

Tabel 4. Hasil Observasi Kemampuan Berbicara Anak Pada Pra tindakan

\begin{tabular}{clccccccc}
\hline No & Penelitian & $\begin{array}{c}\text { Jumlah } \\
\text { Anak } \\
\text { Klasikal }\end{array}$ & BSB & BSH & MB & BB & $\begin{array}{c}\text { Kersentase } \\
\text { Keberiteria } \\
\text { Kelasilan }\end{array}$ & Ket. \\
\hline 1. & $\begin{array}{l}\text { Pra } \\
\text { Tindakan }\end{array}$ & 27 & 0 & 7 & 2 & 18 & $25,92 \%$ & $\begin{array}{c}\text { Belum } \\
\text { Tercapai }\end{array}$ \\
\hline
\end{tabular}

Berdasarkan tabel 4. dapat disimpulkan dalam pra tindakan kelompok B RA Darussalam, Kecamatan Plosoklaten, Kabupaten Kediri belum menunjukkan kemampuan berbicara yang baik. Hasil analisis tabel diperoleh data sebagai berikut. 1) Belum ada anak yang menunjukkan pencapaian berkembang sangat baik, 2) Tujuh dari dua puluh tujuh menunjukkan pencapaian berkembang sesuai harapan, 3) Dua dari dua puluh tujuh anak masih dalam tahap mulai berkembang dan 4) Delapan belas dari dua puluh tujuh anak menunjukkan bahwa anak masih 
dalam tahap belum berkembang Persentase yang ditunjukkan sesuai dengan kriteria keberhasilan kelas pada tahap pra tindakan adalah $25,92 \%$ dengan keterangan belum tercapai.

\subsubsection{Deskripsi Hasil Penelitian Siklus I}

Hasil observasi pelaksanaan tindakan siklus I penerapan metode dongeng dengan media boneka tangan sebagai upaya meningkatkan kemampuan berbicara anak kelompok B RA Darussalam dapat dilihat melalui tabel 5. berikut ini.

Tabel 5. Hasil Observasi Kemampuan Berbicara Anak Pada Siklus I

\begin{tabular}{clccccccc}
\hline No & Penelitian & $\begin{array}{c}\text { Jumlah } \\
\text { Anak } \\
\text { Klasikal }\end{array}$ & BSB & BSH & MB & BB & $\begin{array}{c}\text { Persentase } \\
\text { Kriteria } \\
\text { Keberhasilan } \\
\text { Kelas }\end{array}$ & Ket. \\
\hline 1. & $\begin{array}{l}\text { Siklus I } \\
\begin{array}{l}\text { Pertemuan } \\
\text { Pertama }\end{array}\end{array}$ & 27 & 0 & 9 & 1 & 17 & $33,33 \%$ & $\begin{array}{c}\text { Belum } \\
\text { Tercapai }\end{array}$ \\
\cline { 1 - 7 } & $\begin{array}{l}\text { Siklus I } \\
\text { Pertemuan } \\
\text { Kedua }\end{array}$ & & 3 & 13 & 1 & 10 & $59,25 \%$ & $\begin{array}{c}\text { Mulai } \\
\text { Tercapai }\end{array}$ \\
\hline
\end{tabular}

Berdasarkan tabel 5. dapat disimpulkan dalam siklus I pertemuan pertama kelompok B RA Darussalam belum mencapai hasil yang diinginkan. Hasil analisis tabel diperoleh data sebagai berikut. 1) Belum ada anak yang berkembang sangat baik, 2) Sembilan dari dua puluh tujuh anak menunjukkan pencapaian berkembang sesuai harapan, 3) Satu dari dua puluh tujuh anak menunjukkan pencapaian mulai berkembang dan 4) Tujuh belas dari dua puluh tujuh anak menunjukkan pencapaian belum berkembang. Persentase yang ditunjukkan sesuai dengan kriteria keberhasilan kelas pada siklus I pertemuan pertama adalah 33,33\% dengan keterangan belum tercapai.

Siklus I pertemuan kedua terlihat bahwa terjadi peningkatan pada kelompok B RA Darussalam hanya saja belum mencapai kriteria keberhasilan yang diinginkan. Hasil analisis tabel diperoleh data sebagai berikut. 1) Tiga anak dari dua puluh tujuh anak menunjukkan pencapaian berkembang sangat baik, 2) Tiga belas dari dua puluh tujuh anak menunjukkan pencapaian berkembang sesuai harapan, 3) Satu dari dua puluh tujuh anak menunjukkan pencapaian mulai berkembang dan 4). Sepuluh dari dua puluh tujuh anak menunjukkan pencapaian belum berkembang Persentase yang ditunjukkan sesuai dengan kriteria keberhasilan kelas pada siklus I pertemuan pertama adalah 59,25 \% dengan keterangan mulai tercapai.

Hasil tersebut terlihat bahwa telah terjadi peningkatan pada setiap tahapnya hanya saja belum mencapai kriteria keberhasilan secara keseluruhan kelas B (klasikal). Hal ini dikarenakan untuk mencapai kriteria keberhasilan secara keseluruhan haruslah mencapai $\geq$ $75 \%$, sehingga diperlukan pengulangan pada siklus berikutnya guna memperbaiki hambatan yang terjadi pada siklus I. 


\subsubsection{Deskripsi Hasil Penelitian Siklus II}

Hasil observasi pelaksanaan tindakan siklus II penerapan metode dongeng dengan media boneka tangan sebagai upaya meningkatkan kemampuan berbicara anak kelompok B RA Darussalam dapat dilihat melalui tabel 6. berikut ini.

Tabel 6. Hasil Observasi Kemampuan Berbicara Anak Pada Siklus II

\begin{tabular}{|c|c|c|c|c|c|c|c|c|}
\hline No & Penelitian & $\begin{array}{c}\text { Jumlah } \\
\text { Anak } \\
\text { Klasikal }\end{array}$ & BSB & BSH & MB & BB & $\begin{array}{c}\text { Persentase } \\
\text { Kriteria } \\
\text { Keberhasilan } \\
\text { Kelas }\end{array}$ & Ket. \\
\hline 1. & $\begin{array}{l}\text { Siklus II } \\
\text { Pertemuan } \\
\text { Pertama }\end{array}$ & \multirow{2}{*}{27} & 5 & 14 & 3 & 5 & $70,37 \%$ & $\begin{array}{c}\text { Mulai } \\
\text { Tercapai }\end{array}$ \\
\hline 2. & $\begin{array}{l}\text { Siklus II } \\
\text { Pertemuan } \\
\text { Kedua }\end{array}$ & & 8 & 15 & 3 & 1 & $85,18 \%$ & $\begin{array}{c}\text { Sangat } \\
\text { Tercapai }\end{array}$ \\
\hline
\end{tabular}

Berdasarkan tabel 6. dapat disimpulkan dalam siklus II pertemuan pertama kelompok B RA Darussalam belum mencapai hasil yang diinginkan sesuai dengan kriteria ketercapaian. Hasil analisis tabel diperoleh data sebagai berikut. 1) Lima dari dua puluh tujuh anak menunjukkan pencapaian berkembang sangat baik, 2) Empat belas dari dua puluh tujuh menunjukkan pencapaian berkembang sesuai harapan, 3) Tiga dari dua puluh tujuh anak menunjukkan pencapaian mulai berkembang dan 4) Lima dari dua puluh tujuh menunjukkan pencapaian belum berkembang. Persentase yang ditunjukkan sesuai dengan kriteria keberhasilan kelas pada siklus II pertemuan pertama adalah 70,37 \% dengan keterangan mulai tercapai. Hasil analisis data yang diperoleh dari pelaksanaan siklus II pertemuan kedua telah mencapai kriteria keberhasilan yang diinginkan. Secara keseluruhan dua puluh tiga anak dari dua puluh tujuh anak RA Darussalam, Kecamatan Plosoklaten, Kabupaten Kediri telah memenuhi kriteria keberhasilan dengan persentase sebesar 85,18 \% dengan keterangan sangat tercapai. Persentase yang ditunjukkan pada siklus II pertemuan kedua sudah mencapai $\geq 75 \%$ sehingga sudah memenuhi standar kriteria ketercapaian keberhasilan minimal sehingga dapat dikategorikan siklus II pertemuan kedua sangat tercapai.

\subsection{Pembahasan}

Penelitian tindakan kelas ini dilaksanakan dalam dua siklus. Setiap siklus terdiri dari dua kali pertemuan. Sebelum pelaksanaan tindakan berlangsung, peneliti melakukan pengamatan terhadap kemampuan berbicara anak untuk mengetahui tingkat perkembangan kemampuan berbicara setiap anak dan mengetahui kendala yang ditemui sebagai upaya peningkatan kemampuan berbicara anak. Berbicara adalah suatu keterampilan yang dapat dipelajari dengan berbagai metode yang berbeda. Bicara adalah keterampilan motorik dimana disamping mempelajari bagaimana mengucapkan kata-kata, anak-anak juga harus belajar bagaimana dapat mengaitkan arti dengan kata-kata tersebut. Metode yang dapat dilakukan antara lain dengan metode coba dan ralat (trial and error) atau dengan meniru model tertentu (Hurlock, 1978). Pola belajar berbicara pada semua anak relatif sama, namun dengan tingkat laju perkembangan yang berbeda. Belajar berbicara mencakup tiga proses yang terpisah namun 
saling berkaitan satu sama lain, yaitu belajar mengucapkan kata, membangun kosakata, dan membentuk kalimat.

Hasil data pra tindakan menunjukkan bahwa kemampuan berbicara anak masih belum optimal. Hal tersebut terjadi sebab guru belum memanfaatkan media pembelajaran yang mendukung, sehingga mempengaruhi kondisi anak yang kurang bersemangat dalam mengikuti kegiatan pembelajaran. Media pembelajaran didefinisikan sebagai alat untuk membawa informasi dari satu sumber (guru) kepada penerima (siswa) yang digunakan dalam proses pembelajaran sehingga siswa lebih tertarik mengikuti kegiatan belajar (Kustiawan, 2016). Media pembelajaran yang menarik dan sesuai dengan karakteristik anak dapat membangkitkan minat, perhatian dan kreativitas anak (Mursid, 2015). Jadi media pembelajaran yang menarik dapat merangsang perhatian anak untuk mau mendengarkan dan melaksanakan kegiatan dengan baik.

Kegiatan mendongeng yang dilaksanakan pada penelitian ini dilakukan oleh anak secara langsung dengan memberikan kesempatan pada anak untuk merangkai cerita yang sudah diperdengarkan sebelumnya dan menjawab pertanyaan yang diajukan oleh peneliti. Melalui kegiatan mendongeng dengan boneka tangan, anak diajarkan agar mampu untuk memilih dan memilah kosakata dan menyusun kalimat sendiri dengan bentuk suatu cerita. Hal ini sesuai dengan pernyataan Fadlillah (2012) bahwa bercerita atau mendongeng memberikan kesempatan yang luas kepada anak untuk dapat mengembangkan aspek kebahasaan mereka. Metode dongeng atau metode cerita dalam pendidikan anak usia dini diartikan sebagai metode yang mengisahkan peristiwa atau perbuatan kepada peserta didik melalui tutur kata, ungkapan dan ekspresi wajah. (Fadlillah, 2012). Aspek kebahasaan ini meliputi keterampilan berbicara, membaca, menulis, dan menyimak.

Metode dongeng atau cerita ini merupakan salah satu metode yang memberikan pengajaran berupa pengalaman secara langsung kepada anak melalui cerita yang dituturkan secara lisan sehingga dapat menarik dan mengundang perhatian anak (Moelichatoen, 2004). Metode dongeng merupakan salah satu pemberian pengalaman belajar kepada siswa melalui cerita yang dibawakan secara lisan kepada anak-anak (Mursid, 2016). Metode bercerita adalah salah satu metode pengajaran langsung dengan memberikan pengalaman belajar kepada anak, sebab kegiatan bercerita atau mendongeng diberikan langsung secara lisan kepada anak (Datuamas, 2016).

Kegiatan pembelajaran di Taman Kanak-kanak perlu ditunjang dengan menggunakan media yang tepat sehingga kegiatan lebih menarik. Media pembelajaran diartikan pula sebagai sarana menyampaikan pesan kepada anak didik sehingga pesan yang disampaikan lebih mudah diterima dan dipahami (Fadlillah, 2012). Keberhasilan dalam mengajar di dalam kelas tidak terlepas dari perencanaan pembuatan media tersebut (Susilana \& Cepi, 2007).

Penggunaan media boneka tangan dalam kegiatan mendongeng menunjukkan bahwa anak mulai tertarik dengan kegiatan pembelajaran. Anak antusias menjawab pertanyaan yang diberikan oleh peneliti, dan mengajukan diri ingin maju ke depan kelas untuk mendongeng menggunakan boneka tangan. Hal tersebut menunjukkan bahwa anak mulai terlatih secara verbal. Penerapan metode dongeng dengan media boneka tangan mempunyai langkah-langkah sebagai berikut menurut Mulyani (2013) pertama menyiapkan tujuan pembelajaran yang jelas sehingga media boneka tangan dapat tepat digunakan, kedua penggunaan media boneka tangan ditekankan pada kata-kata yang menggambarkan alur cerita, ketiga permainan boneka 
tangan hendaknya dilaksanakan dalam waktu yang pendek, dan keempat kegiatan mendongeng dengan menggunakan boneka tangan hendaknya melibatkan anak didik.

Pemanfaatan boneka tangan diterapkan dengan cara peneliti mempersiapkan media boneka tangan yang digunakan yaitu bentuk itik, katak, sapi dan monyet. Selanjutnya peneliti menjelaskan cara penggunaan dan fungsi dari boneka tangan. Usai peneliti melakukan kegiatan mendongeng, peneliti mengajukan beberapa pertanyaan berkaitan dengan dongeng yang sudah peneliti bawakan. Setelah beberapa anak menjawab, peneliti mempersilahkan anak-anak untuk maju ke depan kelas mencoba mengulang cerita yang sudah didengarkan sebelumnya. Bagi anak yang mampu bercerita dengan baik dan lancar mendapatkan reward berupa stiker bintang dan buku tulis.

Metode dongeng dengan media boneka tangan ini sangat diminati anak, sebab kegiatannya lebih menyenangkan dibandingkan dengan kegiatan bercerita menggunakan buku cerita kecil atau gambaran di papan tulis. Dari kegiatan mendongeng dengan menggunakan boneka tangan kemampuan berbicara anak lebih terlihat jelas perkembangan kemampuan berbicara anak. Penerapan metode dongeng dengan menggunakan media boneka tangan sangat memberikan kontribusi besar untuk menambah perbendaharaan kosakata anak sehingga mengembangkan kemampuan berbicara.

Berbicara menjadi suatu kemampuan yang penting dan sangat mempengaruhi setiap kehidupan manusia (Tarigan, 2008). Berbicara dapat digunakan untuk saling bertukar pendapat, gagasan, perasaan dan keinginan. Mendongeng dapat mengembangkan imajinasi, berlatih mendengarkan dan menambah perbendaharaan kosakata anak (Mursid, 2015). Berdasarkan teori tersebut, kegiatan mendongeng dapat mengasah kemampuan berbicara anak menjadi lebih lancar dan imajinatif serta memiliki perbendaharaan kosakata yang luas. Jika anak mendongeng dengan menggunakan boneka tangan tidak hanya mengembangkan kemampuan berbicara saja, kemampuan kognitifnya pun ikut berkembang sehingga mampu menyampaikan maksud dan tujuannya dalam kegiatan mendongeng. . Peningkatan kemampuan berbicara anak meningkat secara bertahap pada setiap pertemuan dalam siklus, dimana hal ini dapat dilihat pada tabel 7.

Tabel 7. Peningkatan Kemampuan Berbicara Anak Melalui Metode Dongeng dengan Media Boneka Tangan di RA Darussalam, Kecamatan Plosoklaten, Kabupaten Kediri

\begin{tabular}{|c|c|c|c|c|c|c|c|}
\hline Penelitian & $\begin{array}{l}\text { Jumlah } \\
\text { Anak } \\
\text { Klasikal }\end{array}$ & BSB & BSH & MB & BB & $\begin{array}{c}\text { Persentase } \\
\text { Kriteria } \\
\text { Keberhasilan } \\
\text { Kelas }\end{array}$ & Ket. \\
\hline Pra Tindakan & \multirow{5}{*}{27} & 0 & 7 & 2 & 18 & $25,92 \%$ & $\begin{array}{l}\text { Belum } \\
\text { Tercapai }\end{array}$ \\
\hline $\begin{array}{l}\text { Siklus I Pertemuan } \\
\text { Pertama }\end{array}$ & & 0 & 9 & 1 & 17 & $33,33 \%$ & $\begin{array}{l}\text { Belum } \\
\text { Tercapai }\end{array}$ \\
\hline $\begin{array}{l}\text { Siklus I Pertemuan } \\
\text { Kedua }\end{array}$ & & 3 & 13 & 1 & 10 & $59,25 \%$ & $\begin{array}{c}\text { Mulai } \\
\text { Tercapai }\end{array}$ \\
\hline $\begin{array}{l}\text { Siklus II } \\
\text { Pertemuan } \\
\text { Pertama }\end{array}$ & & 5 & 14 & 3 & 5 & $70,37 \%$ & $\begin{array}{c}\text { Mulai } \\
\text { Tercapai }\end{array}$ \\
\hline $\begin{array}{l}\text { Siklus II } \\
\text { Pertemuan Kedua }\end{array}$ & & 8 & 15 & 3 & 1 & $85,18 \%$ & $\begin{array}{c}\text { Sangat } \\
\text { Tercapai }\end{array}$ \\
\hline
\end{tabular}


Berdasarkan hasil pada tabel 7. dapat dijabarkan bahwa peningkatan terjadi pada setiap siklusnya. Persentase keberhasilan kelas dihitung berdasarkan skor yang diperoleh anak berdasarkan kriteria BSH-BSB atau yang memiliki skor $\geq 75$. Tahap pra tindakan menunjukkan persentase kemampuan berbicara anak sesuai dengan kriteria keberhasilan hanya mencapai $25,92 \%$ yaitu hanya tujuh dari dua puluh tujuh anak dengan keterangan belum tercapai. Siklus I pertemuan pertama menunjukkan persentase kemampuan berbicara anak sesuai dengan kriteria keberhasilan yang meningkat mencapai 33,33\% yaitu sembilan dari dua puluh tujuh anak dengan keterangan belum tercapai. Siklus I pertemuan kedua menunjukkan persentase kemampuan berbicara anak sesuai dengan kriteria keberhasilan yang meningkat mencapai $59,25 \%$ yaitu enam belas dari dua puluh tujuh anak dengan keterangan mulai tercapai. Siklus II pertemuan pertama menunjukkan persentase kemampuan berbicara anak sesuai dengan kriteria keberhasilan yang mencapai peningkatan 70,37\% yaitu sembilan belas dari dua puluh tujuh anak dengan keterangan mulai tercapai. Siklus II pertemuan kedua menunjukkan persentase kemampuan berbicara anak sesuai dengan kriteria keberhasilan yang mencapai peningkatan $85,18 \%$ yaitu dua puluh tiga dari dua puluh tujuh anak dengan keterangan sangat tercapai. Penelitian dihentikan pada siklus II dikarenakan telah memenuhi kriteria ketercapaian yang telah ditentukan yaitu $\geq 75 \%$. Hasil akhir pada siklus II dikatakan berhasil dalam meningkatkan kemampuan berbicara anak melalui metode dongeng dengan menggunakan boneka tangan.

Berdasarkan hasil observasi pra tindakan, siklus I dan siklus II maka diperoleh hasil peningkatan yang sedemikian rupa dari indikator yang sudah ditentukan. Berdasarkan hasil tersebut dapat dikatakan bahwa melalui penerapan metode dongeng dengan media boneka tangan dapat meningkatkan kemampuan berbicara

\section{Simpulan}

Berdasarkan hasil penelitian penerapan metode dongeng dengan media boneka tangan dapat meningkatkan kemampuan berbicara anak kelompok B RA Darussalam, Kecamatan Plosoklaten, Kabupaten Kediri. Penerapan metode dongeng dengan media boneka tangan ini dapat meningkatkan kemampuan berbicara anak yang mulanya belum optimal, menjadi optimal. Pembelajaran menjadi lebih menyenangkan karena dengan metode dongeng dan media boneka tangan anak menjadi tertarik dalam melaksanakan kegiatan pembelajaran. Anak secara langsung diberikan kesempatan untuk merangkai cerita yang sudah diperdengarkan sebelumnya, sehingga secara tidak langsung melatih kemampuan berbicara.

Kemampuan berbicara anak melalui metode dongeng dengan media boneka tangan terbukti dari anak lebih aktif kegiatan pembelajaran. Kemampuan berbicara anak terlihat dari anak mampu menjawab pertanyaan yang lebih kompleks, memiliki perbendaharaan kosakata yang luas dan mampu menceritakan dongeng atau cerita yang sudah didengar. Kemampuan berbicara anak dalam satu kelas mengalami peningkatan secara bertahap dari pra tindakan 25,92\% menjadi 33,33\% pada siklus 1 pertemuan pertama, dan meningkat menjadi 59,25\% pada pertemuan kedua. Pada siklus II pertemuan pertama meningkat menjadi 70,37\% dan pada pertemuan kedua menjadi $85,18 \%$.

\section{Daftar Rujukan}

Arikunto, S. (2012). Penelitian Tindakan Kelas. Jakarta: Bumi Aksara

Fadlillah, M. (2012). Desain Pembelajaran PAUD. Yogyakarta: Ar Ruzz Media

Hurlock, E. (1978). Perkembangan Anak Jilid 1. Jakarta: Erlangga 
Jurnal Pembelajaran, Bimbingan, dan Pengelolaan Pendidikan, 1(5), 2021, 362-372

Hurlock, E. (1980). Psikologi Perkembangan Suatu Pendekatan Sepanjang Rentang Kehidupan. Jakarta: Erlangga Kustiawan, U. (2016). Pengembangan Media Pembelajaran Anak Usia Dini. Malang: Gunung Samudera

Meggit, Carolyn. (2013). Memahami Perkembangan Anak. Jakarta:PT Indeks

Moeslichatoen. (2004). Metode Pengajaran di Taman Kanak-kanak. Jakarta:PT Rineka Cipta

Morrison, G. S. (2016). Pendidikan Anak Usia Dini Saat Ini. Yogyakarta: Pustaka Pelajar

Mulyani, S. A. (2013). Penggunaan Boneka Sebagai Media Simulasi Kreatif di Sekolah Dasar. Jurnal Pemikiran dan Pengembangan Sekolah Dasar (JP2SD), 1(2), 20-25.

Mursid. (2015). Belajar dan Pembelajaran PAUD. Bandung:PT Remaja Rosdakarya

Peraturan Menteri Pendidikan Nasional Nomor 137 tahun 2014 Tentang Standar Nasional Pendidikan Anak Usia Dini Perguruan Tinggi.

Seefeldt, C. \& Barbara A. W. (2008). Pendidikan Anak Usia Dini. Jakarta:PT Indeks

Slee, P. T. (2002). Child, adolescent and family development (Vol. 2). Cambridge University Press.

Sudijono, A. (2014). Pengantar Statistik Pendidikan. Jakarta:PT Rajagrafindo Persada

Susilana, R. \& Riyana, C. (2007). Media Pembelajaran. Bandung:CV Wacana Prima.

Suyadi. (2015). Teori Pembelajaran Anak Usia Dini Dalam Kajian Neurosains. Bandung:PT Remaja Rosdakarya

Tarigan, H. G. (2008). Berbicara Sebagai Suatu Keterampilan Berbahasa. Bandung: Angkasa 